\title{
Determination of five mineral element contents in pollen grains of different seedling date palm (Phoenix Dactylifera L.) male trees grown in fayoum Governorate, Egypt
}

\begin{abstract}
This experiment was conducted to found the connection between sensible male pollinators and the content from mineral element (Zinc, Iron, Manganese, Cupper and Magnesium) in pollen grain of fifty seedling date palm male and compared it with the best selective five seedling date palm males (number 2, 10, 29, 40, 46) are appropriate and promising males for to be utilized in pollinating female date palms and mistreatment in breeding programs in previous study. Results found variations among the categories of pollen and elements. The highest concentration of zinc was found in males' number $(2,10,40$ and 46) which recorded 127,102, 115 and 122 $\mu \mathrm{g} / \mathrm{g}$ dry weight respectively as compared to the other male trees. Also the highest concentration of iron was found in male number (40) which recorded $222 \mu \mathrm{g} / \mathrm{g}$ dry weight as compared to the other male trees. Moreover, notes from result excellence male number (10) in manganese concentration which recorded $202 \mu \mathrm{g} / \mathrm{g}$ dry weight as compared to the other male trees. In this concern, pollen grain of date palm male trees contained also, high concentrations of copper and magnesium the concentration ranging from 10 to 30 and 1320 to $1985 \mu \mathrm{g} / \mathrm{g}$ dry weight for copper and magnesium respectively. The best value for copper and magnesium which obtained from the selective male number (46) which recorded 30 and $1985 \mu \mathrm{g} / \mathrm{g}$ dry weight for copper and magnesium respectively as compared to the other male trees. From all the results we can conclude that the date palm pollen grain was as rich source of important minerals, so its suitability as a regular component in plant and human diet.
\end{abstract}

Volume 3 Issue 3 - 2019

\author{
Mohamed A Seif El Yazal,' Samir A Seif El \\ Yazal, ${ }^{2}$ \\ 'Botany Department, Faculty of Agriculture, Fayoum University, \\ Egypt \\ ${ }^{2}$ Horticulture Department, Faculty of Agriculture, Fayoum \\ University, Egypt
}

\begin{abstract}
Correspondence: Mohamed A Seif El Yazal, Professor of Plan Physiology, Botany Department, Faculty of Agriculture, Fayoum University, Egypt, Email mas04@fayoum.edu.eg
\end{abstract}

Received: December 03, 2018 | Published: May 28, 2019

Keywords: male date pal, zinc, iron, manganese, cupper, magnesium

\section{Introduction}

Date palm (Phoenix dactylifera L.) is one amongst the oldest cultivated trees in world. In Egypt, Phoenix dactylifera tree is taken into account joined of the foremost vital fruits wherever it's cosmopolitan in numerous areas in Egypt from the Mediterranean coast up to Assouan. It's cosmopolitan in numerous districts of the planet districts of the world. It constitutes the foremost vital plant in arid and desert areas wherever it provides favorable conditions for both human and animal habitats. ${ }^{1}$ In fact, feather palm as Associate in Nursing irreplaceable tree in irrigable desert lands grows underneath unfavorable conditions wherever several of the opposite fruit species doesn't. It additionally keeps alternative crops settled under that from heat, wind, and even cold weather. So, it plays an enormous role to prevent geologic process and provides life to desert areas.,3 Date palm could be a dioecious perennial and monocotyledonous fruit tree that belongs to the Arecaceae family. Several investigators studied the effect of pollens obtained from totally different palm males cultivar on fruit set, yield and fruit physical and chemical properties of many female palm cultivars. ${ }^{4-10}$ The direct influence of the male parent on the event of the date fruit is precise and definite and varies with the actual male wont to fertilize the female flowers. Every male exerting just about constant impact on fruit of all varieties and exerting constant impact in several years. Therefore, it's vital to select and identify superior male in term of fertilization. The concentration of mineral components in spore grains of feather date palm males were studied by many workers. ${ }^{11-21}$ In addition, several investigators mentioned that, the effect of micro-nutrient in spore grain germination and pollen tube growth in several plant species. ${ }^{22,23}$ The minerals content in pollen grains differed from one seedling plant males to a different. The macronutrients, $\mathrm{N}$ was gift within the highest concentrations, followed by $\mathrm{Ca}, \mathrm{P}, \mathrm{Mg}$ and $\mathrm{Na}$, whereas the micronutrients, $\mathrm{Fe}$ was gift within the highest concentrations, followed by $\mathrm{Zn}, \mathrm{Mn}$ and $\mathrm{Cu}^{24}$ The aim of this analysis area unit study the content of those five types of nutrients (Zinc, Iron, Manganese, Cupper and Magnesium) in pollen grain of the selective five seedling date palm males and compare them with those of alternative males because these elements are importance within the life of the plant wherever any shortage leads to intensive harm to the plant. Moreover, these males might be used as pollinators for palm females. Also, we are able to propagate and multiply these promising males' oldsters by tissue cultural programs. Moreover, we wish to indicate is that the content of those elements are correlated with the rise in pollination and fertilization process or not.

\section{Materials and methods}

\section{Plant materials}

The study was conducted during the three successive seasons 2015, 2016 and 2017 on fifty seedling date palm males about 30 years old and grown in Sand clay loamy soil at Tamiya district, Fayoum Governorate, Egypt. Moreover, the study included the five date palm 
males coded by numbers $(2,10,29,40$ and 46$)$ which select according to the evaluation results of more previously studies. ${ }^{8-10}$ as good male pollinators for further using in pollinating female date palms and breeding programs.

\section{Collection of plant material}

Date Palm pollen was collected in March (2015, 2016 and 2017) from Tamiya district, Fayoum Governorate, Egypt. Some of palm pollen grains (Phoenix dactylifera L.) were collected and separated from the kernels with a fine gauze sieve and dried at $70^{\circ} \mathrm{C}$ and then kept in closed container.

\section{Chemical composition:}

Dried pollen grain were used for determination, Iron, zinc, manganese, copper and magnesium contents as $\mu \mathrm{g} / \mathrm{g}$ dry weight by using atomic absorption spectrophotometer apparatus according. ${ }^{25,26}$ Data were statistically analyzed according. ${ }^{27}$ Data presented in the Table of this investigation represent the mean of the three experimental seasons.

\section{Results}

\section{Micro nutrient}

Zinc concentrations: Data presented in Table 1 indicate that Pollen grain of date palm male trees contained high concentrations of zinc, the concentration ranging from 49 to $127 \mu \mathrm{g} / \mathrm{g}$ dry weight .The best result which obtained from the selective males number $(2,10,40$ and 46) which recorded $127,102,115$ and $122 \mu \mathrm{g} / \mathrm{g}$ dry weight respectively as compared to the other male trees.

Iron concentrations: Data presented in Table 2 indicate that Pollen grain of date palm male trees contained also high concentrations of iron, the concentration ranging from 145 to $222 \mu \mathrm{g} / \mathrm{g}$ dry weight. The best result which obtained from the selective male number (40) which recorded $222 \mu \mathrm{g} / \mathrm{g}$ dry weight respectively as compared to the other male trees.

Manganese concentrations: Data presented in Table 3 indicate that Pollen grain of date palm male trees contained high concentrations of iron, the concentration ranging from 97 to $202 \mu \mathrm{g} / \mathrm{g}$ dry weight .The best result which obtained from the selective male number (10) which recorded $202 \mu \mathrm{g} / \mathrm{g}$ dry weight respectively as compared to the other male trees.

Copper concentrations: Data presented in Table 4 indicate that pollen grain of date palm male trees contained low concentrations of copper, the concentration ranging from 10 to $30 \mu \mathrm{g} / \mathrm{g}$ dry weight .The best result which obtained from the selective male number (46) which recorded $30 \mu \mathrm{g} / \mathrm{g}$ dry weight respectively as compared to the other male trees.

\section{Macro nutrient}

Magnesium concentrations: Data presented in Table 5 indicate that Pollen grain of date palm male trees contained high concentrations of magnesium, the concentration ranging from 1320 to $1985 \mu \mathrm{g} / \mathrm{g}$ dry weight. The best result which obtained from the selective male number (46) which recorded $1985 \mu \mathrm{g} / \mathrm{g}$ dry weight respectively as compared to the other male trees.
Table I Pollen zinc content of date palm males as the mean of the three seasons studied

\begin{tabular}{|c|c|c|c|c|c|}
\hline \multirow[t]{2}{*}{$\begin{array}{l}\text { Male } \\
\text { No. }\end{array}$} & \multicolumn{2}{|c|}{$\begin{array}{l}\text { Zn } \mu g / g \text { dry } \\
\text { weight }\end{array}$} & \multirow[t]{2}{*}{ Male No. } & \multicolumn{2}{|c|}{ Zn $\mu g / g$ dry weight } \\
\hline & Mean* & C.V**. & & Mean* & C.V.** \\
\hline I & 88 & 3.13 & 26 & 92 & 1.25 \\
\hline 2 & 127 & 3.62 & 27 & 95 & 1.95 \\
\hline 3 & 95 & 1.33 & 28 & 70 & $2.4 I$ \\
\hline 4 & 93 & 6.31 & 29 & 98 & 2.63 \\
\hline 5 & 74 & 1.43 & 30 & 81 & 1.01 \\
\hline 6 & 55 & 2.67 & 31 & 63 & 2.14 \\
\hline 7 & 62 & $2.6 I$ & 32 & 66 & 1.92 \\
\hline 8 & 81 & 1.43 & 33 & 53 & 2.33 \\
\hline 9 & 49 & 3.58 & 34 & 84 & 1.36 \\
\hline 10 & 102 & 4.14 & 35 & 84 & 1.85 \\
\hline II & 73 & 1.4 & 36 & 90 & 2.06 \\
\hline 12 & 92 & 6.25 & 37 & 77 & 1.35 \\
\hline 13 & 94 & 6.71 & 38 & 94 & 1.18 \\
\hline 14 & 82 & 1.66 & 39 & 63 & 2.55 \\
\hline 15 & 83 & 1.86 & 40 & 115 & 3.02 \\
\hline 16 & 83 & 1.17 & 41 & 51 & 1.18 \\
\hline 17 & 60 & 2.01 & 42 & 65 & 1.66 \\
\hline 18 & 64 & 1.95 & 43 & 83 & 1.22 \\
\hline 19 & 58 & 1.18 & 44 & 90 & 1.28 \\
\hline 20 & 79 & 1.77 & 45 & 95 & 1.35 \\
\hline 21 & 88 & 2.03 & 46 & 122 & 2.47 \\
\hline 22 & 67 & 1.18 & 47 & 59 & 1.35 \\
\hline 23 & 72 & 3.64 & 48 & 57 & 1.48 \\
\hline 24 & 75 & 3.22 & 49 & 92 & 1.79 \\
\hline 25 & 83 & 1.84 & 50 & 64 & 1.45 \\
\hline
\end{tabular}

Mean of seasons, 20I5, 2016and 2017*

Coefficient of variation** 
Table 2 Pollen iron content of date palm males as the mean of the three seasons studied

\begin{tabular}{|c|c|c|c|c|c|}
\hline \multirow[t]{2}{*}{$\begin{array}{l}\text { Male } \\
\text { No. }\end{array}$} & \multicolumn{2}{|c|}{$\begin{array}{l}\text { Fe } \mu g / g \text { dry } \\
\text { weight }\end{array}$} & \multirow[t]{2}{*}{ Male No. } & \multicolumn{2}{|c|}{ Fe $\mu g / g$ dry weight } \\
\hline & Mean* & C.V**. & & Mean* & C.V.** \\
\hline I & 167 & 12.67 & 26 & 148 & 5.15 \\
\hline 2 & 184 & 12.54 & 27 & 183 & 9.21 \\
\hline 3 & 204 & 8.25 & 28 & 199 & 25.15 \\
\hline 4 & 201 & 8.11 & 29 & 149 & 10.28 \\
\hline 5 & 217 & 9.01 & 30 & 162 & 12.2 \\
\hline 6 & 193 & 13.73 & 31 & 208 & 9.28 \\
\hline 7 & 205 & 9.18 & 32 & 174 & II.II \\
\hline 8 & 221 & 9.25 & 33 & 172 & 12.55 \\
\hline 9 & 145 & 10.21 & 34 & 160 & 6.18 \\
\hline 10 & 188 & 21.05 & 35 & 231 & 10.14 \\
\hline II & 198 & 20.18 & 36 & 153 & 6.33 \\
\hline 12 & 200 & 10.11 & 37 & 160 & $\mid 4.25$ \\
\hline 13 & 182 & 11.18 & 38 & 178 & 16.6 \\
\hline 14 & 164 & 9.85 & 39 & 192 & 15.66 \\
\hline 15 & 145 & 10.85 & 40 & 193 & 15.35 \\
\hline 16 & 222 & 8.55 & 41 & 184 & 14.2 \\
\hline 17 & 191 & 9.84 & 42 & 205 & 10.18 \\
\hline 18 & 203 & 8.95 & 43 & 209 & 10.89 \\
\hline 19 & 175 & 15.1 & 44 & 187 & 11.33 \\
\hline 20 & 188 & $|2.2|$ & 45 & 161 & 8.61 \\
\hline 21 & 207 & 13.15 & 46 & 222 & 14.15 \\
\hline 22 & 202 & 25.18 & 47 & 176 & 15.04 \\
\hline 23 & 170 & 14.36 & 48 & 206 & 21.18 \\
\hline 24 & 177 & 10.15 & 49 & 202 & 10.74 \\
\hline 25 & 216 & 8.85 & 50 & 185 & 9.78 \\
\hline
\end{tabular}

Mean of seasons, 2015,2016 and $2017^{*}$

**Coefficient of variation
Table 3 Pollen manganese content of date palm males as the mean of the three seasons studied

\begin{tabular}{|c|c|c|c|c|c|}
\hline \multirow[t]{2}{*}{$\begin{array}{l}\text { Male } \\
\text { No. }\end{array}$} & \multicolumn{2}{|c|}{ Mn $\mu g / g$ dry weight } & \multirow[t]{2}{*}{$\begin{array}{l}\text { Male } \\
\text { No. }\end{array}$} & \multicolumn{2}{|c|}{ Mn $\mu g / g$ dry weight } \\
\hline & Mean* & C.V**. & & Mean* & C.V.** \\
\hline 1 & 134 & 15.14 & 26 & 129 & 3.25 \\
\hline 2 & 191 & 12.1 & 27 & 133 & 5.68 \\
\hline 3 & 182 & 15.05 & 28 & 97 & 3.54 \\
\hline 4 & 178 & 12.28 & 29 & 136 & 10.54 \\
\hline 5 & 112 & 10.18 & 30 & 189 & 10.25 \\
\hline 6 & 98 & 3.25 & 31 & 194 & 12.25 \\
\hline 7 & 155 & 5.16 & 32 & 203 & 11.82 \\
\hline 8 & 192 & 8.65 & 33 & 158 & 9.28 \\
\hline 9 & $|4|$ & 7.99 & 34 & 182 & 8.92 \\
\hline 10 & 202 & 12.63 & 35 & 179 & 10.25 \\
\hline II & 154 & 8.15 & 36 & 192 & 9.44 \\
\hline 12 & 177 & 6.58 & 37 & 186 & 8.15 \\
\hline 13 & 168 & 9.65 & 38 & 172 & 6.18 \\
\hline 14 & 136 & 6.85 & 39 & 194 & 10.52 \\
\hline 15 & 121 & 10.21 & 40 & 157 & 8.25 \\
\hline 16 & 166 & 13.05 & 41 & 142 & 5.15 \\
\hline 17 & 192 & 12.15 & 42 & 154 & 4.27 \\
\hline 18 & 143 & 6.17 & 43 & 193 & 9.88 \\
\hline 19 & 129 & 5.25 & 44 & 171 & 10.55 \\
\hline 20 & 155 & 9.18 & 45 & 185 & 11.33 \\
\hline 21 & 181 & 11.21 & 46 & 157 & 12.25 \\
\hline 22 & 138 & 10.84 & 47 & 142 & 10.22 \\
\hline 23 & I4I & 13.13 & 48 & 194 & 10.54 \\
\hline 24 & 174 & 14.85 & 49 & 173 & 12.12 \\
\hline 25 & 187 & 17.38 & 50 & 184 & 16.1 \\
\hline
\end{tabular}

Mean of seasons, 2015,2016 and $2017^{*}$

Coefficient of variation** 
Table 4 Pollen Cupper content of date palm males as the mean of the two seasons studied

\begin{tabular}{|c|c|c|c|c|c|c|c|c|c|c|c|}
\hline \multirow[t]{2}{*}{ Male No. } & \multicolumn{2}{|c|}{ Cu $\mu g / g$ dry weight } & \multirow[t]{2}{*}{$\begin{array}{l}\text { Male } \\
\text { No. }\end{array}$} & \multicolumn{2}{|c|}{$\begin{array}{l}\text { Cu } \mu g / g \text { dry } \\
\text { weight }\end{array}$} & \multirow[t]{2}{*}{$\begin{array}{l}\text { Male } \\
\text { No. }\end{array}$} & \multicolumn{2}{|c|}{$\begin{array}{l}\text { Mg } \mu g / g \text { dry } \\
\text { weight }\end{array}$} & \multirow[t]{2}{*}{ Male No. } & \multicolumn{2}{|c|}{ Mg $\mu g / g$ dry weight } \\
\hline & Mean* & C.V**. & & Mean* & C.V.** & & Mean* & C.V**. & & Mean* & C.V.** \\
\hline I & 16 & 3.12 & 26 & 14 & I.I4 & I & 1330 & 16.05 & 26 & 1840 & 16.33 \\
\hline 2 & 10 & 2.16 & 27 & 13 & 1.35 & 2 & 1670 & 17.28 & 27 & 1940 & 15.17 \\
\hline 3 & 22 & 5.24 & 28 & 24 & 1.58 & 3 & 1450 & 18.33 & 28 & 1450 & 12.32 \\
\hline 4 & 14 & 2.01 & 29 & 21 & 1.87 & 4 & 1940 & 18.54 & 29 & 1320 & 14.25 \\
\hline 5 & 25 & 2.18 & 30 & 19 & 1.65 & 5 & 1680 & 18.69 & 30 & 1520 & 15.26 \\
\hline 6 & 32 & 3.24 & 31 & 23 & 1.24 & 6 & 1130 & 19.04 & 31 & 1830 & 17.77 \\
\hline 7 & 30 & 3.58 & 32 & 15 & 1.65 & 7 & 1980 & 19.35 & 32 & 1220 & 18.39 \\
\hline 8 & 29 & 2.66 & 33 & 21 & 1.38 & 8 & 1320 & 16.33 & 33 & 1340 & 14.35 \\
\hline 9 & II & 1.23 & 34 & 12 & 1.59 & 9 & 1960 & 16.54 & 34 & 1530 & 16.33 \\
\hline 10 & 17 & 1.65 & 35 & 26 & $\mathrm{I} .34$ & 10 & 1340 & $|8.2|$ & 35 & 1820 & 17.28 \\
\hline II & 14 & 1.21 & 36 & 22 & 2.01 & II & 1460 & 16.16 & 36 & 1470 & 17.95 \\
\hline 12 & 13 & 1.68 & 37 & 18 & 2.35 & 12 & 1970 & 15.24 & 37 & 1960 & 16.13 \\
\hline 13 & 15 & 1.38 & 38 & 29 & 3 & 13 & 1950 & 15.36 & 38 & 1780 & 16.19 \\
\hline 14 & 12 & I.65 & 39 & 15 & I.I5 & 14 & 1350 & 16.66 & 39 & 1660 & 18.17 \\
\hline 15 & 18 & 2.12 & 40 & 27 & 2.01 & 15 & 1930 & 16.32 & 40 & 1430 & 13.25 \\
\hline 16 & 15 & 2.52 & 41 & 23 & 2.05 & 16 & 1720 & $|7.2|$ & 41 & 1940 & 16.25 \\
\hline 17 & 20 & 1.32 & 42 & 20 & 2.06 & 17 & 1880 & 19.18 & 42 & 1350 & 11.38 \\
\hline 18 & 19 & 2.58 & 43 & 14 & I. 32 & 18 & 1930 & 19.32 & 43 & 1230 & 16.35 \\
\hline 19 & 23 & 2.84 & 44 & 28 & 1.89 & 19 & 1490 & 14.13 & 44 & 1680 & 10.82 \\
\hline 20 & 21 & 2.44 & 45 & 24 & I.54 & 20 & 1360 & 12.16 & 45 & 1920 & 18.39 \\
\hline 21 & 24 & 2.86 & 46 & 30 & 2.06 & 21 & 1500 & 13.15 & 46 & 1985 & 10.1 \\
\hline 22 & 13 & 2.47 & 47 & 15 & I.II & 22 & 1830 & 14.25 & 47 & 1840 & 11.66 \\
\hline 23 & 20 & 2.38 & 48 & 29 & I.42 & 23 & 1610 & 14.36 & 48 & 1670 & 15.25 \\
\hline 24 & 23 & 2.65 & 49 & 12 & I.II & 24 & 1450 & 15.15 & 49 & 1450 & 13.25 \\
\hline 25 & 30 & 2.98 & 50 & 25 & 1.68 & 25 & 1720 & 16.26 & 50 & 1940 & 16.21 \\
\hline
\end{tabular}

Mean of seasons, 2015, 2016and 2017*

Coefficient of variation**
Mean of seasons, 2015, 2016and 2017*

Table 5 Pollen magnesium content of date palm males as the mean of the three seasons studied

Coefficient of variation** 


\section{Discussion}

It is clear from the current information that the great male pollinators for using in pollinating female date palms (five seedling date palm males number, $2,10,29,40,46)$ was characterized by high content of the estimated element (Zinc, Iron, Manganese, Cupper and Magnesium). In this respect, ${ }^{24}$ pointed that feather date palm pollen (phoenix dactylifera $L$ ) is particulary high mineral content. This could be associated with the high mineral content of the soil horizons in dry areas wherever this species grows. But, the capability of the parent plant to accumulate elements within the pollen is additionally associated with the species. Moreover ${ }^{19}$ found that Egyptian pollen grain contain higher quantity of copper 3.196 $\mathrm{mg} / \mathrm{g}$ with lower quantity of manganese $2.84 \mathrm{mg} / \mathrm{g}$, zinc $2.81 \mathrm{mg} / \mathrm{g}$ and iron $2.41 \mathrm{mg} / \mathrm{g}$. The elements $\mathrm{Fe}, \mathrm{Mg}, \mathrm{Mn}, \mathrm{Zn}$ and $\mathrm{Cu}$ have been classified as essential elements for the plants and human $\operatorname{diet}^{28,29}$ While not copper, iron cannot be properly reborn to its usable ${ }^{30}$ whereas the $\mathrm{Mg}$ contain within the pollen grains is also reduced risk of stroke. ${ }^{31}$ The presence of $\mathrm{Mg}^{+2}, \mathrm{Cu}^{+3}, \mathrm{Fe}^{+2}, \mathrm{Mn}^{+2}$ and $\mathrm{Zn}^{+2}$ reflects their perform as essential nutrient components, typically as cofactor activators in metal-ligand enzyme complexes. ${ }^{29}$ The healthful importance of pollen grain could also be thanks to its content of $\mathrm{Zn}$ that is beneficial to manufacture of testosterone, as antioxidant and essential for traditional functioning of the male reproductive system, ${ }^{29,32}$ in contribution of $\mathrm{Mn}^{33}$ which also are essential for traditional functioning of central system nervosum and are an honest anti-oxidant. ${ }^{29}$ Workers, rumored that, iron plays a task in syntheses of RNA, reduction of nitrate to ammonia, ${ }^{34}$ chlorophyll synthesis, ${ }^{35}$ nucleic acid metabolism and chemical change and structural roles of $\mathrm{Fe}^{++}$and $\mathrm{Fe}^{+++}$in plant. ${ }^{36}$ Also, iron is either a constituent or a cofactor of many antioxidant enzymes, and might acts as a pro-oxidant issue as a result of free or loosely bound $\mathrm{Fe}^{-}$catalyses free radical generation within the presence of reductants and peroxides through the Fenton reaction. In particular, $\mathrm{Fe}$ is involved in the $\mathrm{Fe}^{-}$catalysed Haber-Weiss reaction in which trace amounts of $\mathrm{Fe}^{3+}$ are reduced by to produce $\mathrm{Fe}^{2+}$ which, in turn, reacts with $\mathrm{H}_{2} \mathrm{O}_{2}$ to form $\mathrm{OH}$ (Fenton reaction). As the intrinsic constituent or metal compound, iron is actively concerned in cellular detoxification reactions catalysed by enzyme, phenolicdependent peroxidases (non-specific peroxidases, ascorbate peroxidases and metallic element SOD, that scavenge oxideand superoxide, therefore protective the cell from aerophilous injury. As the intrinsic constituent or metal cofactor, iron is actively concerned in cellular detoxification reactions catalysed by enzyme catalase, phenolic-dependent peroxidases (non-specific peroxidases, ascorbate peroxidases and $\mathrm{Fe}$ superoxide dismutase, which scavenge hydrogen peroxide and superoxide, therefore protective the cell from aerophilous injury.. In this respect, ${ }^{37}$ reported that, iron deficient helianthus plants appears to have an effect on totally different the various peroxidase isoenzymes to different extents and to induce a secondary aerobic oxidative stress, as indicated by the redoubled levels of $\mathrm{H}_{2} \mathrm{O}_{2}$. On the opposite hand, the foremost vital perform of manganese is said to the oxidation-reduction processes..$^{28}$ It may be used as a cofactor of many enzymes that act as phosphorylated substrates; conjointly, it plays a task in control the amount of plant hormones (auxins) in plant tissues by activating the auxin oxidation system. ${ }^{34}$ The essential role of atomic number 30 is said to the synthesis of essential amino acid organic compound and consequently formation of phytohormone i.e. IAA that act as plant hormone particularly in prolonging height of plants. ${ }^{38}$ Metal has a rolein supermolecule metabolism, supermolecule synthesis, essential amino acid and IAA synthesis, since it activates variety of enzymes for photosynthesis. ${ }^{39,40}$ The essential role of $\mathrm{Zn}$ is related to the synthesis of tryptophan amino acid and consequently formation of phytohormon i.e. IAA that act as plant hormone particularly in prolonging height of plants. $^{38}$ Zinc has a vital role in carbohydrate metabolism, protein synthesis, essential amino acid and IAA synthesis, since it activates variety of enzymes for photosynthesis..$^{39,40}$ Also, ${ }^{41}$ rumored that, the rise in spore grain from $\mathrm{Mg}, \mathrm{Zn}, \mathrm{Mn}$, iron and atomic number 29 is various components of the plant. The stimulating impact of micronutrients on plant growth is also because of their role in lepton transmission from water to chlorophyll and manufacturing $\mathrm{O}$ gas within the chemical change, additionally to their role within the gas metabolism through activated group enzyme catalyst. ${ }^{42}$ Also, the favorable impact of $\mathrm{Mg}, \mathrm{Zn}, \mathrm{Fe}, \mathrm{Mn}$ and atomic number 29 on yield and its elements in antecedently studied by ${ }^{8,9}$ may be attributed to the rise in photosynthetic pigments concentration ${ }^{36}$ moreover as, catalyst activity, consequently improvement of plant metabolism. ${ }^{43}$ Also ${ }^{41}$ reported that, the rise in Pollen grain from $\mathrm{Mg}, \mathrm{Zn}, \mathrm{Mn}, \mathrm{Fe}$ and $\mathrm{Cu}$ also because of the impact of $\mathrm{Zn}$ on synthesis of phytohormone (I.A.A.) that promote ontogenesis process and consequently the amounts of mineral elements absorbed and trans placed into the various components of the plant. The stimulating impact of micronutrients on plant growth is also because of their role in electron transmission from water to chlorophyll and manufacturing oxygen gas within the photosynthesis, additionally to their role within the nitrogen metabolism through activated nitrite reductase enzyme..$^{42}$ Also, the favorable impact of $\mathrm{Mg}, \mathrm{Zn}, \mathrm{Fe}, \mathrm{Mn}$ and $\mathrm{Cu}$ on yield and its components in antecedently studied by ${ }^{8,9}$ may be attributed to the rise in photosynthetic pigments concentration ${ }^{36}$ moreover as, enzyme activity, consequently improvement of plant metabolism. ${ }^{43}$

\section{Conclusion}

Finally, from the present results, it could be concluded that the good male pollinators for using in pollinating female date palms was characterized by high content from elements (Zinc, Iron, Manganese, Copper and Magnesium). Which reflected greatly on fertility and yield, and consequently improved quality of fruits because these elements participate in the different metabolic processes. Moreover, it could be recommended to fertilizing date palm males trees with micronutrients of ( $\mathrm{Fe}, \mathrm{Zn}, \mathrm{Mn}, \mathrm{Cu}, \mathrm{Mg}$ ) for increase vitality of Pollen grains of date Palm male trees and greatly increased yield.

\section{Acknowledgments}

None.

\section{Conflicts of interest}

The author declares there is no conflicts of interest.

\section{References}

1. Khoshroo SMR. Seed storage protein electrophoretic profiles in some Iranian date palm (Phoenix dactylifera L.) cultivars. African Journal of Biotechnology. 2011;10(77):17793-17804.

2. Baliga MS, Baliga BRV, Kandathil SM, et al. A review of the chemistry and pharmacology of the date fruits (Phoenix dactylifera L.). Food Research International. 2011;44(7):1812-1822.

3. Mohamed Ahmed MVO, Bouna ZEO, Mohamed Lemine FM, et al. Use of multivariate analysis to assess phenotypic diversity of date palm (Phoenix dactylifera L.) cultivars. Scientia Horticulturae. 2011;127(3):367-371. 
4. Ghnaim HD, Al Muhtaseb JA. Effect of Pollen Source on Yield, Quality and Maturity of 'Mejhool' Date Palm. Jordan Journal of Agricultural Sciences. 2006;2:8-15.

5. Metwaly HAA, Abou Rekab ZAM, Abd El Baky AA, et al. Evaluation of some seeded date palm trees grown in Fayoum Governorate. B-chemical characteristics. $4^{\text {th }}$ Conference on Recent Technologies in Agriculture. $2009 ; 701-715$.

6. Swaed SY. Superficial study of pollen grains of some agricultural varieties of date palm. Basra Journal of Research Date Palm. 2009;8:81-93.

7. El Kosary S. Characteristics of four Barhee date strains as affected by pollen source and pollination time. J of Hort Sci \& Ornmental Plants. 2009;1:79-91.

8. Moustafa AA, Ibrahim ZA, Seif El Yazel SA, et al. Evaluation and selection of some seedling Date palm Males Grown at Fayoum Governorate. 2010.

9. Moustafa AA, Ibrahim ZA, Seif El Yazel SA, et al. Evaluation of different selected seedling date palm males in pollination of "SEEWY" Date palm grown In fayoum Governorate, Egypt. 2010.

10. Seif El Yazal SA, Alharby HF, Seif El Yazal MA, et al. Molecula identification of some seedling of date palm (Phoenix dactylifera L.) males trees. The Journal of Animal \&Plant Sciences. 2017;27(4):1287-1294.

11. Jasim AM, Ibrahim AO, Abbas MF. Certain physicochemical change during growth and maturity of Hillw. Basrah J Agric Sci. 1995;8:2.

12. Jasim AM, Yousef AY, Al Jubouri S. The use of neutron activation analysis technique for estimating protein and mineral elements in the pollen of different varieties of male palm. Basra Agricultural Science Journal. $2000 ; 13: 41-55$

13. Abed MA. Determine of carbohydrates, protein and phenolic compounds content in pollen grains of three of Palm Phoenix dactylifera. Basrah Journal for Date Palm Research. 2000;4(1-2):141-149.

14. Abed MA, El Tememy EH. Determination of three elements in pollen grains of different date palm. Basra Journal of Agricultural Science. 2006;19(1):73-80.

15. Abed AM, Abdul Wahid AH, Al Tamimi EH. Some trace elements concentration (trace) in three varieties of agricultural pollen of date palm. Basra Journal of Agricultural Science. 2007;20:7784

16. Abed AM, Abdul Wahid AH, Abbas MF. Studing the content of three palm pollen grains varieties from cytokinins, calcium and boron content. Basra Journal of Agricultural Science. 2008;2:64-65.

17. Abed MA, Hantosh AA, AL Saad HT, et al. Seasonal variations of some biochemical aspects for five species of date palm (2-trace elements). Basra Science Journal. 2011;37:50-66.

18. Swaed SY, Aty ME. Determine mineral content for four elements of pollen grains of two date palm cultivars. Basrah Journal For Date Palm Research. 2011;10:141-149.

19. Hassan HMM. Chemical composition and nutritional value of palm pollen 4 Grains. Global Journal of Biotechnology \& Biochemistry. 2011;6(1):1-7.

20. Abdel Rheem DA, Hassan HM, Ahmed SA, et al. Investigation and comparison of lipid content and nutritional composition of different organs of Brahea armata- S. Watson, Family Arecaceae, growing in Egypt. Journal of American Science. 2015;11:87-93.

21. Al Samarai AH, Al Salihi FG, Al Samarai RR. Phytochemical constituents and nutrient evaluation of date palm (Phoenix dactylifera, L.) pollen grains. Tikrit Journal of Pure Science. 2016;21:56-62.

22. Talaie A, Badmahmoud AT, Malakout MG. The effect of foliar application of N, B and $\mathrm{Zn}$ on quantitative and qualitative characteristics of olive fruit. Iranian J Agric Sci. 2001;32:727-736.
23. Wojcik P, Wojcik M. Effect of boron fertilization on conference pear tree vigor, nutrition and fruit yield and storability. Plant and Soil. $2003 ; 256(2): 413-421$.

24. Stanley RG, Linskens HF. Pollen biology, chemistry and management. Springerverlage, New York. 1974.

25. Chapman HD, Pratt PF. Methods of analysis of soil, plants and water. Soil Science. 1962;93(1):68.

26. Zade MB, Salunke SD. Total mineral content of rare fruits grown in latur district. Hi-Tech Research Analysis 2011;1:6-10.

27. Snedecor GW, Cochran WG. Statistical methods. $7^{\text {th }}$ Edn. Iowa State Univ press, Ames, Iowa, USA. 1980

28. Mengel K, Kirkby EA. Principles of plant narration, $3^{\text {rd }}$ Publisher, International Potash Institute, Worbalaufen- Bern /Switzerland. 1982;593655

29. Zafar M, Khan MA, Ahmad M, et al. Elemental analysis of some medicinal plants used in traditional medicine by atomic absorption spectrophotometer (AAS). Journal of Medicinal Plants Research. 2010;4(19):1987-1990.

30. Lopez MA, Martos FC. Iron availability: An updated review. Int J Food Sci Nutr. 2004;55(8):597-606

31. Larsson SC, Orsini N, Wolk A. Dietary magnesium intake and risk of stroke: a meta-analysis of prospective studies. Am J Clin Nutr. 2012;95(2):362366.

32. Ali H, Ahmed M, Baig M. Relationship of zinc concentrations in serum and seminal plasma with various semen parameters in infertile subjects. Pak J Med Sci. 2007·23(1):111-114.

33. Bansal AK, Kaur ARJ. Cooperative functions of manganese and thiol redox system against oxidative stress in human spermatozoa. J Hum Reprod Sci. 2009;2(2):76-80.

34. Russell SEW. Soil conditions and plant growth. $11^{\text {th }}$ Edn. 1989.

35. Romheld W, Maschnur H. Micronutrients in Agriculture. $2^{\text {nd }}$ Edn. Soil Sci Society of America. USA. 1961;297.

36. Price CA, Clark HE, Funkhouser EA. Function of micronutrients in plants Soil Sci Society of America. 1972;231:136-148.

37. Ranieri A, Castagna A, Baldan B, et al. Iron deficiency differently affects peroxidase isoforms in sunflower. $J$ Exp Bot. 2001;52(354):25-35.

38. Devendra T, Najda CL, Tak D. Effect of growth regulators on growth and flower yield of tuberouse (Polianthes tuberosa L.) cv. single. Scientific Hort. 1999; 6:147-150.

39. Gardner FP, Prearce RB, Mitcheell RL. Physiology of crop plants. The Iowa State Univ Press, Ames, Iowa, U.S.A. 1985.

40. Marschner H. Mineral nutrition of higher plants. $2^{\text {nd }}$ Edn. Academic Press Inc. (London) LTD, 1986.

Devlin RM, Withman FH. Plant Physiology. $4^{\text {th }}$ Edn. CBS Publishers and Distribution. 1983.

42. Baza MS. Effect of some macro and micro elements on growth and yields of maize. Fac Agric of Moshtohr, Zagazig Univ, Egypt. 1984.

43. Boardman NK. Trace-elements in photosynthesis. In trace elements in SoilPlant Animal System. Academic Press. Inc., New York . San Francisco and London. 1975. 